\title{
Comparison of the deleterious effects of yaji and cadmium chloride on testicular physiomorphological and oxidative stress status: The gonadoprotective effects of an omega-3 fatty acid
}

\author{
Ehitare Ikekhuamen Ekhoye', Samson Eshikhokhale Olerimi' ${ }^{2}$, Santos Ehizokhale Ehebha ${ }^{3}$ \\ Departments of ${ }^{1}$ Physiology, ${ }^{2}$ Biochemistry, and ${ }^{3}$ Anatomy, College of Medical Sciences, Edo University lyamho, lyamho, Nigeria
}

Objective: This study investigated testicular oxidative stress status and physiomorphological function in Wistar rats fed with yaji and cadmium chloride $\left(\mathrm{CdCl}_{2}\right)$.

Methods: Sixty male albino Wistar rats (12 per group) were randomly assigned to five groups: group I (control), group II (300 mg/kg.bw of yaji), group III (500 mg/kg.bw of yaji), group IV ( $2.5 \mathrm{mg} / \mathrm{kg} . b w$ of $\left.\mathrm{CdCl}_{2}\right)$, and group V ( $2.5 \mathrm{mg} / \mathrm{kg} . b w$ of yaji+4 mg/kg.bw omega-3). Each group was evenly subdivided into two subgroups and treatment was administered for 14 days and 42 days, respectively. Semen quality (sperm count, progressive motility, normal morphology, and gonadosomatic index), hormones (testosterone, follicle-stimulating hormone, and luteinizing hormone), testicular oxidative stress markers (superoxide dismutase, catalase, glutathione peroxidase, and malonaldehyde) and testicular histomorphological features were examined.

Results: Yaji caused significant $(p<0.05)$ dose- and duration-dependent reductions in semen quality, the gonadosomatic index, testosterone, follicle-stimulating hormone, and luteinizing hormone. Yaji also caused significant $(p<0.05)$ dose- and duration-dependent decreases in superoxide dismutase, catalase, and glutathione peroxidase activity, as well as increased testicular malonaldehyde levels. Yaji induced distortions in the testicular histological architecture. $\mathrm{CdCl}_{2}$ damaged testicular function by significantly $(p<0.05)$ reducing semen quality, reproductive hormone levels, and oxidative stress markers in albino Wistar rats. $\mathrm{CdCl}_{2}$ also altered the histology of the testis.

Conclusion: This study shows that yaji sauce has similar anti-fertility effects to those of $\mathrm{CdCl}_{2}$, as it adversely interferes with male reproduction by impairing oxidative stress markers and the function and morphological features of the testis.

Keywords: Antioxidant; Cadmium chloride; Capsaicin; Infertility; Omega-3; Oxidative stress; Reactive oxygen species; Semen quality; Sperm count; Yaji

Received: January 13, 2020 Revised: Febuary 13,2020 · Accepted: April 1, 2020 Corresponding author: Ehitare Ikekhuamen Ekhoye

Department of Physiology, College of Medical Sciences, Edo University lyamho is the city, Edo State, Nigeria

Tel: +234-7038648797 E-mail: ekhoye.ehitare@edouniversity.edu.ng

*This work was supported by grant no. 06-2018-097 from the Edo University lyamho Research Fund.

This is an Open Access article distributed under the terms of the Creative Commons Attribution Non-Commercial License (http://creativecommons.org/licenses/by-nc/4.0/) which permits unrestricted non-commercial use, distribution, and reproduction in any medium, provided the original work is properly cited.

\section{Introduction}

Fertility issues are a major global health concern, and infertility is defined by the World Health Organization as a "disease of human reproduction, and it is defined by the inability to achieve clinical pregnancy after 12 months or more of unprotected and regular sexual intercourse" [1]. Infertility poses a significant public health challenge in Nigeria and many other developing countries because of its high prevalence and serious social complications for affected couples and families. In some parts of sub-Saharan Africa, including Nigeria, Sudan, 
and Cameroon, the infertility rate may exceed $30 \%[2,3]$. In southeastern Nigeria, previous studies have demonstrated $65 \%$ and $35 \%$ prevalence rates for primary and secondary infertility, respectively [4].

Male-related factors contribute to more than $30 \%$ of fertility problems [5]. Several factors are known to interfere with fertility, including drug treatment [6], environmental toxins, air pollution [7], and stress [8]; however, approximately $50 \%$ of male infertility cases are attributed to idiopathic causes [9]. Nonetheless, a possible etiology for this pathological situation may be an increase in oxidative stress (OS). In recent years, $\mathrm{OS}$ has attracted major interest for its potential role in the physiopathology of male fertility and testicular function [10]. Elevation of OS results from a disparity between the generation of OS markers and the antioxidant defense system [11].

Despite ongoing debates about the benefits and health risks of additives [12,13], along with their known hazardous effects [14], food additives still remains a major constituent of dietary consumption in Nigeria. Suya, a meat product, is served with yaji, a complex mixture of various spices and additives including cloves, red pepper, ginger, black pepper, salt, monosodium glutamate, and groundnut cake powder [15]. These spices and additives contain phytochemical constituents such as eugenol [16], capsaicin [17], gingerol and zingiberol [18], and piperine [19]. The high rate of consumption and the chemical complexity of yaji [20] have raised concerns over the years about its indiscriminate and unregulated pattern of ingestion [21].

Omega-3 fatty acids are a class of polyunsaturated fatty acids that cannot be synthesized in vivo, and are therefore considered to be essential [22]. Studies have proven that omega-3 fatty acids exert powerful protective effects on the male reproductive system of rats exposed to toxic substances [23] through their antioxidant and anti-inflammatory properties $[24,25]$.

Cadmium chloride $\left(\mathrm{CdCl}_{2}\right)$ is a salt of a heavy metal that is a potent carcinogen in rats [26] and humans [27]. It has previously been established that the liver, gonads, and kidney are target sites for cadmium toxicity in mammals [28-31]. Furthermore, $\mathrm{CdCl}_{2}$ has been reported to exert toxic effects on selected tissues via the production of reactive oxygen species and by inhibiting cell proliferation and DNA replication [30], but data on gonadotoxicity are scarce.

The available scientific data show that a disproportionately high consumption of yaji is capable of inducing kidney [32], pancreatic [33], liver [34], brain tissue [21,35], and heart [36] damage; therefore, it is necessary to investigate its effects on other vital organs, such as the testes, to clarify its role in male fertility. On this basis, the present study was designed to assess changes in the reproductive function and testicular $\mathrm{OS}$ status of albino Wistar rats following acute and subchronic oral ingestion of yaji.

\section{Methods}

\section{Animals and experimental design}

Sixty albino Wistar rats of reproductive age (10 to 12 weeks old) weighing around $180-220 \mathrm{~g}$ were obtained from the Animal House, College of Medical Sciences, Edo University lyamho. The animals were acclimatized within a 2-week period to become accustomed to the environmental conditions of the laboratory. During the experiment, all the animals were treated according to the standard procedures laid down by Organization for Economic Co-operation and Development guidelines.

Animals were randomly divided into five groups of 12 rats each. In group I (control group), each rat was given distilled water. In group II, the rats were orally treated with yaji ( $300 \mathrm{mg} / \mathrm{kg} . \mathrm{bw}$ per day), and in group III, the rats were orally treated with yaji ( $500 \mathrm{mg} / \mathrm{kg} . b w$ per day). In group IV, the rats were orally treated with $\mathrm{CdCl}_{2}(2.5 \mathrm{mg} / \mathrm{kg}$.bw per day). Finally in group $V$, the rats were orally treated with yaji $(500 \mathrm{mg} /$ kg.bw per day) and omega-3 ( $4 \mathrm{mg} / \mathrm{kg} . b w$ per day). Each group was divided into two subgroups, in which treatments were administered orally for 14 days and 42 days, corresponding to acute and subchronic administration, respectively.

\section{Ethical approval and consent to participate}

This study (RBC/FBMS/DELSU/14/09) was approved by the Research and Bio-Ethics Committee of the Faculty of Basic Medical Science, Delta State University, Abraka, Nigeria. The procedures of animal handling adhered to the ethical principles outlined in the Declaration of Helsinki.

\section{Agents for administration \\ 1) Yaji (suya)}

Dried yaji sauce was purchased daily from the General Market in Auchi, Edo State, Nigeria. Specific concentrations of yaji sauce were mixed with the rat feed. The selected doses were $300 \mathrm{mg} / \mathrm{kg} . \mathrm{bw}$ and $500 \mathrm{mg} / \mathrm{kg} . \mathrm{bw}$, and were prepared according to procedures described in the previous literature [15].

\section{2) Omega-3 fatty acid}

An omega-3 fatty acid in gelatin capsules was purchased from the local chemist's shop in Auchi, Nigeria.

\section{3) Cadmium chloride}

$\mathrm{CdCl}_{2}$ and Tween 20 used for this study were purchased from Sigma-Aldrich (St. Louis, MO, USA). All other reagents were of analytical grade. 


\section{Samples collection and analysis}

At the end of the experiment, the animals were sacrificed by cervical dislocation and were quickly dissected to remove the testes. After removal, the right testes were placed immediately into a container containing Bouin's fluid for subsequent histological processing of the testicular tissues. The left testes were measured for weight and volume, and subsequently homogenized to obtain tissue OS markers. Blood samples were taken via cardiac puncture into plain tubes and centrifuged at 3,600 rpm for 15 minutes. Serum samples were immediately collected and used for hormonal analysis.

\section{Semen quality measurements}

The cauda epididymis of each rat was excised and seminal fluid was milked onto a glass slide for measurements of forward sperm motility, sperm count, and sperm morphology.

\section{1) Sperm motility}

To assess the percentage of progressive sperm motility, the method described by Zemjanis [37] was used. A drop of semen was placed on a glass slide, after which $2.9 \%$ sodium citrate was added. This was covered with another glass slip, and then fields were viewed under light microscopy to assess the proportions of motile and non-motile spermatozoa.

\section{2) Sperm count}

The number of spermatozoa was estimated with the use of a hemocytometer. The cauda epididymis was minced in normal saline and then filtered, after which an aliquot of $10 \mu \mathrm{L}$ was placed on the hemocytometer. An improved Neubauer chamber (Deep 1/10 m, LABART; Munich, Germany) was used for the count, under a light microscope. The sperm count was carried out according to a previously described method [38].

\section{3) Sperm morphology}

Sperm morphology was analyzed by staining a drop of semen suspension with Papanicolaou stain, which was then smeared on a glass slide. The smear was allowed to dry under sunlight and subsequently examined using a light microscope at $\times 100$ magnification. The percentage of normal sperm morphology was determined using a protocol from the previous literature [39].

\section{Histomorphometric analysis}

The testes of each rat were fixed in Bouin's fluid, passed through an ascending series of ethanol grades and then through xylene, after which they were embedded in paraffin wax. The tissues were sectioned at an appropriate thickness for hematoxylin and eosin and mounted. All sections were examined under light microscopy at $\times 100$ magni- fication. Photomicrographs were taken for tissue observations and histopathological lesions were documented.

\section{Gonadosomatic index}

Measurements of the body weight and the testicular weight of each Wistar rat were made using a weighing balance. The mean testicular and body weights of the rats were used to derive the gonadosomatic index for each rat using the formula: gonadosomatic index $\left({ }^{\circ}\right)=$ testicular weight/body weight $\times 100$ [40].

\section{Hormonal assays}

Serum follicle-stimulating hormone (FSH), luteinizing hormone (LH), and testosterone levels were ascertained using radio-immunoassay kits (Fortress Diagnostics, Antrim, UK). To maintain proper experimental standards of these hormones, the normal plasma concentration ranges were first established, and animals with levels outside these limits were excluded. Furthermore, to prevent variation in plasma concentrations of the hormones, all the rats were handled in a similar fashion.

\section{Preparation of the tissue homogenate}

Testis homogenate was prepared using $1.17 \% \mathrm{KCl}$ in an ice-cold phosphate buffer with a $\mathrm{pH} 7.4$ and a concentration of $0.1 \mathrm{M}$ for the preparation of a $10 \%$ homogenate solution of each testis sample. To estimate the lipid peroxidation levels, part of this homogenate was utilized and the remaining solution was centrifuged at 10,000 rpm for 10 minutes at a temperature of $40^{\circ} \mathrm{C}$. The supernatant was decanted and used for the antioxidant enzymatic assays (superoxide dismutase, catalase, and glutathione peroxidase).

\section{1) Lipid peroxidation}

An assay was done to quantify testicular malondialdehyde (MDA) levels. To every $1 \mathrm{~mL}$ of homogenate, $10 \%$ trichloroacetic acid ( $1 \mathrm{~mL}$ ) was added, followed by an incubation period of 10 minutes at room temperature. The mixture of solutions was later centrifuged for another 15 minutes at $2,500 \mathrm{rpm}$ at $37^{\circ} \mathrm{C}$. Furthermore, $1 \mathrm{~mL}$ of the supernatant was then added to $1 \mathrm{~mL}$ of $0.67 \%$ thiobarbituric acid and left for 20 minutes in a hot water bath. Later, these test tubes were kept under running water to cool them. Subsequently, distilled water ( $1 \mathrm{~mL}$ ) and $5 \mathrm{~mL}$ of $\mathrm{n}$-butanol:pyridine were added to the tubes, followed by another centrifugation. The butanol layer in the supernatant was separated and absorbance readings were subsequently taken at $320 \mathrm{~nm}$. The units of the results were represented in nanomoles of MDA formed per milligram of protein [41].

\section{2) Superoxide dismutase enzyme assay}

To determine the superoxide dismutase activity in testes, the pyro- 
Table 1. Effects of yaji on sperm count, progressive sperm motility, normal sperm morphology, and gonadosomatic index of rats

\begin{tabular}{|c|c|c|c|c|c|}
\hline Variable & Control & 300 mg/kg.bw yaji & 500 mg/kg.bw yaji & $\mathrm{CdCl}_{2}$ & $\begin{array}{c}500 \text { mg/kg.bw yaji+ } \\
4 \text { mg/kg.bw omega-3 }\end{array}$ \\
\hline \multicolumn{6}{|c|}{ Sperm count $\left(\times 10^{6}\right.$ cells $\left./ \mathrm{mm}^{3}\right)$} \\
\hline 42 Days & $52.00 \pm 6.33$ & $27.00 \pm 5.32^{\mathrm{a}, \mathrm{b})}$ & $24.00 \pm 2.69^{\mathrm{a})}$ & $15.00 \pm 6.34^{\mathrm{a})}$ & $30.00 \pm 6.03^{b)}$ \\
\hline \multicolumn{6}{|c|}{ Progressive motility (\%) } \\
\hline 21 Days & $68.5 \pm 3.16$ & $55.74 \pm 8.22^{b)}$ & $42.00 \pm 7.31^{\mathrm{b})}$ & $23.67 \pm 2.58^{\mathrm{a})}$ & $45.50 \pm 6.40^{b)}$ \\
\hline 21 Days & $72.00 \pm 11.77$ & $68.67 \pm 8.48^{b)}$ & $45.00 \pm 8.41^{\mathrm{a})}$ & $41.25 \pm 7.46^{a)}$ & $64.67 \pm 4.67^{b)}$ \\
\hline 42 Days & $72.8 \pm 10.84$ & $66.77 \pm 9.31^{\mathrm{b})}$ & $38.57 \pm 6.09^{\mathrm{a}, \mathrm{c}}$ & $37.00 \pm 7.74^{\text {a) }}$ & $62.00 \pm 3.48^{\mathrm{b})}$ \\
\hline \multicolumn{6}{|c|}{ Gonadosomatic index } \\
\hline 21 Days & $0.88 \pm 0.03$ & $0.82 \pm 0.02^{b)}$ & $0.74 \pm 0.02^{\mathrm{b})}$ & $0.41 \pm 0.05^{\mathrm{a})}$ & $0.77 \pm 0.02^{b)}$ \\
\hline 42 Days & $0.91 \pm 0.01$ & $0.84 \pm 0.03^{b)}$ & $0.68 \pm 0.02^{\mathrm{a}, \mathrm{b})}$ & $0.45 \pm 0.05^{\mathrm{a})}$ & $0.80 \pm 0.01^{\mathrm{b})}$ \\
\hline
\end{tabular}

Values are presented as mean \pm standard error of the mean $(n=6)$.

$\mathrm{CdCl}_{2}$, cadmium chloride.

${ }^{\text {a) }} p<0.05$ when compared with the control group; ${ }^{\text {b) }} p<0.05$ when compared with the group treated with $\mathrm{CdCl}_{2} ;{ }^{c} p<0.05$ when compared with the group treated with yaji for 21 days.

gallol autoxidation procedure was followed. A supernatant of $0.5 \mathrm{~mL}$ was obtained from the tissue homogenate, and was mixed with 250 $\mu \mathrm{L}$ of absolute ethanol and $150 \mu \mathrm{L}$ of chloroform. Subsequently, the tubes were kept in a mixer for 15 minutes, followed by centrifugation. Then, $2 \mathrm{~mL}$ of $0.1 \mathrm{M}$ Tris $\mathrm{HCl}$ with a $\mathrm{pH}$ of 8.2 was mixed into the $0.5-\mathrm{mL}$ supernatant, along with $1 \mathrm{~mL}$ of distilled water and $0.5 \mathrm{~mL}$ of pyrogallol solution. With a time interval of 1 minute between each reading, the absorbance was read at $420 \mathrm{~nm}$ for 3 minutes. The results for enzymatic activity were expressed as $\mathrm{U} / \mathrm{mg}$ protein [42].

\section{3) Catalase activity}

The assay was carried out based on the principles described by Sinha [43]. A solution of $0.4 \mathrm{~mL}$ of distilled water with $1 \mathrm{~mL}$ of $0.01 \mathrm{M}$ phosphate buffer at a pH of 7.0 was mixed, followed by the addition of $0.5 \mathrm{~mL}$ of $\mathrm{H}_{2} \mathrm{O}_{2}(0.2 \mathrm{M})$. The mixed solution was then incubated at $37^{\circ} \mathrm{C}$ for 1 minute. Potassium dichromate with a volume of $2 \mathrm{~mL}$ was used as the stopping reagent for the reaction. The tubes were then placed for 15 minutes in a hot water bath. The results for enzymatic activity were expressed as $\mathrm{U} / \mathrm{mg}$ protein.

\section{4) Action of glutathione peroxidase}

To estimate testicular glutathione peroxidase activity, $0.4 \mathrm{~mL}$ of a $0.4 \mathrm{M}$ phosphate buffer with a $\mathrm{pH}$ of 7.0 was mixed with $4 \mathrm{mM}$ glutathione $(0.2 \mathrm{~mL}), 2.5 \mathrm{mM} \mathrm{H}_{2} \mathrm{O}_{2}(0.1 \mathrm{~mL})$, distilled water $(0.2 \mathrm{~mL})$ and $10 \mathrm{mM}$ sodium azide $(0.1 \mathrm{~mL})$; this was added to $0.1 \mathrm{~mL}$ of the supernatant solution. After incubating this solution for 10 minutes at $37^{\circ} \mathrm{C}$, $10 \%$ trichloroacetic acid $(0.5 \mathrm{~mL})$ was added. After another incubation period for a 30 minutes, the mixture was centrifuged for 10 minutes at 1,500 rpm. The supernatant obtained was then separated and mixed with Ellman's reagent (DTNB, $0.5 \mathrm{~mL}$ ) and $0.3 \mathrm{M} \mathrm{Na}_{2} \mathrm{HPO}_{4}(4 \mathrm{~mL})$. The absorbance readings were taken at $412 \mathrm{~nm}$ at a time interval of $1 \mathrm{~min}$ ute to 3 minutes [44].

\section{Statistical analysis}

Statistical analysis was done using one-way analysis of variance along with the least significant difference test as a post hoc test, since the data of all groups were normally distributed. The data were represented in the format of mean \pm standard error of the mean. A $p$-value $<0.05$ was considered to indicate statistical significance. The statistical analysis was carried out using GraphPad ver. 6.03 (GraphPad Software, San Diego, CA, USA).

\section{Results}

Table 1 shows the effects of graded concentrations of yaji and $\mathrm{CdCl}_{2}$ on sperm count, the progressive motility of sperm, sperm morphology, and the gonadosomatic index of Wistar rats. The data indicate that yaji caused a dose-dependent decrease in semen quality parameters and the gonadosomatic index. The decrease in sperm count and percentage of sperm with normal morphology were statistically significant $(p<0.05)$ following 21 days of yaji treatment when compared to the control group, while 42 days of yaji treatment caused significant $(p<0.05)$ diminutions in sperm count, the progressive motility of sperm, the percentage of sperm with normal morphology, and the gonadosomatic index. $\mathrm{CdCl}_{2}$ was observed to significantly $(p<0.05)$ decrease the semen quality parameters and gonadosomatic index when compared to the control group and rats treated with yaji sauce. Non-significant differences were observed in sperm count and the 
percentage of sperm with normal morphology in rats treated with $500 \mathrm{mg} / \mathrm{kg}$.bw of yaji when compared to those treated with $\mathrm{CdCl}_{2}$ after 21 days. Co-administration of $4 \mathrm{mg} / \mathrm{kg}$.bw of omega-3 and 500 $\mathrm{mg} / \mathrm{kg}$.bw of yaji caused a general and significant $(p<0.05)$ improvement in all the sperm parameters (sperm motility, count, and morphology) and gonadosomatic index when compared to the $\mathrm{CdCl}_{2}$ group, but a non-significant reduction was observed in sperm motility, count, and morphology when compared to the control. Yaji sauce also caused a duration-dependent decrease in semen quality parameters and the gonadosomatic index; these decreases were not significant, except that 42 days of treatment with $500 \mathrm{mg} / \mathrm{kg} . \mathrm{bw}$ of yaji caused a significant $(p<0.05)$ decrease in the percentage of sperm with normal morphology when compared to rats that received 21 days of treatment with $500 \mathrm{mg} / \mathrm{kg} . \mathrm{bw}$ of yaji.

Table 2 shows the effect of yaji and $\mathrm{CdCl}_{2}$ on serum concentrations of testosterone, $\mathrm{FSH}$, and LH. Yaji caused a dose-dependent decrease in serum testosterone levels with a maximal effect observed over a longer duration of administration. Yaji significantly $(p<0.05)$ reduced testosterone levels in a dose-dependent manner following 45 days of administration, and this decrease was also significant $(p<0.05)$ when compared with the testosterone level of rats treated with yaji for 21 days. Yaji caused minimal effects on the FSH and LH level following 21 days of treatment, but caused a significant $(p<0.05)$ and dose-dependent decrease in serum gonadotropins after 42 days of treatment. $\mathrm{CdCl}_{2}$ significantly $(p<0.05)$ decreased serum concentrations of testosterone, $\mathrm{FSH}$, and $\mathrm{LH}$ when compared to the control and yaji groups. The reduction in testosterone caused by $\mathrm{CdCl}_{2}$ was not significantly different $(p<0.05)$ from that observed in rats treated with $500 \mathrm{mg} / \mathrm{kg}$.bw of yaji for 42 days. Similarly, $\mathrm{CdCl}_{2}$ also caused significant $(p<0.05)$ reductions in $\mathrm{FSH}$ and $\mathrm{LH}$ when compared to yaji-treated rats. The decreases in testosterone, FSH, and $\mathrm{LH}$ levels caused by $\mathrm{CdCl}_{2}$ were duration-dependent, as significant $(p<0.05)$ reductions in the hormone concentrations were observed in rats treated with $\mathrm{CdCl}_{2}$ for 42 days when compared with rats treated for 21 days. Omega-3 co-administration with $500 \mathrm{mg} / \mathrm{kg}$.bw of yaji was observed to cause ameliorating effects, as shown by improved testosterone, $\mathrm{FSH}$, and LH serum levels, which were significantly $(p<0.05)$ higher than in rats treated with $\mathrm{CdCl}_{2}$.

Table 3 shows the effects of yaji and $\mathrm{CdCl}_{2}$ on testicular superoxide dismutase, catalase, glutathione peroxidase, and malonaldehyde. Yaji caused dose- and duration-dependent decreases in superoxide dismutase, catalase, and glutathione peroxidase activity. The decrease in superoxide dismutase activity in rats treated with $500 \mathrm{mg} / \mathrm{kg} . \mathrm{bw}$ of yaji was significant $(p<0.05)$ when compared to the control group. The administration of $500 \mathrm{mg} / \mathrm{kg}$.bw of yaji for 42 days caused a significant $(p<0.05)$ decrease in superoxide dismutase activity when compared to rats treated for 21 days. Yaji accelerated testicular lipid peroxidation, as a dose-dependent increase in testicular malonaldehyde levels was observed, with significant $(p<0.05)$ increases in rats treated with $500 \mathrm{mg} / \mathrm{kg} . b w$ of yaji. The administration of $500 \mathrm{mg} / \mathrm{kg} . \mathrm{bw}$ of yaji for 42 days caused a significant $(p<0.05)$ increase in malonaldehyde levels when compared to rats treated for 21 days. $\mathrm{CdCl}_{2}$ significantly $(p<0.05)$ decreased superoxide dismutase, catalase, and glutathione peroxide activity in the testes. It caused significant $(p<$ 0.05 ) increases in malonaldehyde levels in the testes. The observed changes in $\mathrm{OS}$ markers following $\mathrm{CdCl}_{2}$ administration were durationdependent. The $\mathrm{CdCl}_{2}$-induced decreases in superoxide dismutase and glutathione peroxidase activity in rats treated for 42 days were significant $(p<0.05)$ in comparison to rats treated for 21 days. The omega-3 fatty acid augmented the effects of testicular antioxidants by increasing superoxide dismutase, catalase, and glutathione peroxidase activity. It also attenuated lipid peroxidation in the testes, as shown by decreased malonaldehyde levels. Prolonged administration of the omega-3 fatty acid caused significant $(p<0.05)$ changes

Table 2. Effects of yaji on testosterone, follicle-stimulating hormone, and luteinizing hormone levels in rats

\begin{tabular}{|c|c|c|c|c|c|}
\hline Variable & Control & 300 mg/kg.bw yaji & 500 mg/kg.bw yaji & $\mathrm{CdCl}_{2}$ & $\begin{array}{c}500 \text { mg/kg.bw yaji+ } \\
4 \text { mg/kg.bw omega-3 }\end{array}$ \\
\hline \multicolumn{6}{|c|}{ Testosterone (ng/mL) } \\
\hline 21 Days & $6.70 \pm 0.10$ & $5.40 \pm 0.10$ & $4.20 \pm 0.11^{\mathrm{a})}$ & $2.80 \pm 0.08^{\mathrm{a})}$ & $3.80 \pm 0.22^{\mathrm{a})}$ \\
\hline 42 Days & $6.80 \pm 0.05$ & $3.25 \pm 0.03^{\mathrm{a}, \mathrm{b}, \mathrm{c})}$ & $1.02 \pm 0.11^{\mathrm{a}, \mathrm{c})}$ & $0.70 \pm 0.04^{\mathrm{a}, \mathrm{c}}$ & $4.41 \pm 0.20^{b)}$ \\
\hline \multicolumn{6}{|c|}{ Follicle-stimulating hormone (mIU/L) } \\
\hline 21 Days & $8.11 \pm 0.30$ & $8.23 \pm 1.03^{b)}$ & $7.86 \pm 1.25^{b)}$ & $1.71 \pm 0.10^{\mathrm{a})}$ & $8.02 \pm 1.43^{b)}$ \\
\hline 42 Days & $9.14 \pm 1.24$ & $7.64 \pm 0.46^{b)}$ & $7.55 \pm 1.16^{b)}$ & $0.93 \pm 0.40^{\mathrm{a}, \mathrm{c}}$ & $8.66 \pm 1.77^{\mathrm{b})}$ \\
\hline \multicolumn{6}{|c|}{ Luteinizing hormone (mIU/L) } \\
\hline 21 Days & $11.6 \pm 1.19$ & $11.03 \pm 1.52^{b)}$ & $10.67 \pm 1.77^{b)}$ & $2.60 \pm 0.08^{\mathrm{a})}$ & $10.43 \pm 1.93^{b)}$ \\
\hline 42 Days & $10.76 \pm 0.47$ & $10.00 \pm 1.14^{b)}$ & $8.67 \pm 1.04^{b)}$ & $1.42 \pm 0.10^{\mathrm{a}, \mathrm{c}}$ & $9.11 \pm 2.00^{b)}$ \\
\hline
\end{tabular}

Values are presented as mean \pm standard error of the mean $(n=6)$.

$\mathrm{CdCl}_{2}$, cadmium chloride.

${ }^{\text {a) }} p<0.05$ when compared with the control group; ${ }^{\text {b) }} p<0.05$ when compared with the group treated with $\mathrm{CdCl}_{2} ;{ }^{\mathrm{c}} p<0.05$ when compared with the group treated with yaji for 42 days. 
Table 3. Effects of yaji on testicular superoxide dismutase, catalase, and glutathione peroxidase activity, and malonaldehyde levels in rats

\begin{tabular}{|c|c|c|c|c|c|}
\hline Variable & Control & 300 mg/kg.bw yaji & 500 mg/kg.bw yaji & $\mathrm{CdCl}_{2}$ & $\begin{array}{l}500 \text { mg/kg.bw yaji+ } \\
4 \text { mg/kg.bw omega-3 }\end{array}$ \\
\hline \multicolumn{6}{|c|}{ Superoxide dismutase (U/mg protein) } \\
\hline 21 Days & $15.07 \pm 0.20$ & $11.07 \pm 0.20^{\mathrm{a})}$ & $10.74 \pm 0.31^{\mathrm{a})}$ & $7.00 \pm 0.14^{\mathrm{a})}$ & $8.70 \pm 0.15^{\mathrm{a})}$ \\
\hline 42 Days & $16.03 \pm 0.14$ & $11.45 \pm 0.20^{b)}$ & $8.70 \pm 0.25^{\mathrm{a}, \mathrm{c}}$ & $5.30 \pm 0.10^{\mathrm{a}, \mathrm{c}}$ & $10.00 \pm 0.20^{b)}$ \\
\hline \multicolumn{6}{|c|}{ Catalase (U/mg protein) } \\
\hline 21 Days & $13.00 \pm 0.24$ & $11.14 \pm 0.12$ & $9.68 \pm 0.05$ & $7.70 \pm 0.14^{\mathrm{a})}$ & $8.13 \pm 0.66$ \\
\hline 21 Days & $34.64 \pm 2.17$ & $27.45 \pm 4.01$ & $24.78 \pm 1.65$ & $25.10 \pm 1.78$ & $30.10 \pm 3.58$ \\
\hline 42 Days & $37.06 \pm 2.41$ & $24.27 \pm 3.11$ & $21.33 \pm 3.27$ & $18.67 \pm 1.08^{\mathrm{a}, \mathrm{c}}$ & $28.16 \pm 2.21$ \\
\hline \multicolumn{6}{|c|}{ Malonaldehyde (nmol/mg) } \\
\hline 21 Days & $1.92 \pm 0.06$ & $2.64 \pm 0.04^{\mathrm{a})}$ & $2.86 \pm 0.18^{\mathrm{a})}$ & $4.10 \pm 0.16^{\mathrm{a})}$ & $2.12 \pm 0.07$ \\
\hline 42 Days & $1.47 \pm 0.05$ & $2.73 \pm 0.15^{\mathrm{a})}$ & $3.61 \pm 0.11^{\mathrm{a})}$ & $4.63 \pm 0.15^{\mathrm{a})}$ & $1.96 \pm 0.13^{\mathrm{b}, \mathrm{c}}$ \\
\hline
\end{tabular}

Values are presented as mean \pm standard error of the mean $(n=6)$.

$\mathrm{CdCl}_{2}$, cadmium chloride.

a) $p<0.05$ when compared with the control group; b) $p<0.05$ when compared with the group treated with $\mathrm{CdCl}_{2} ;{ }^{\mathrm{c}} p<0.05$ when compared with the group treated with yaji for 42 days.
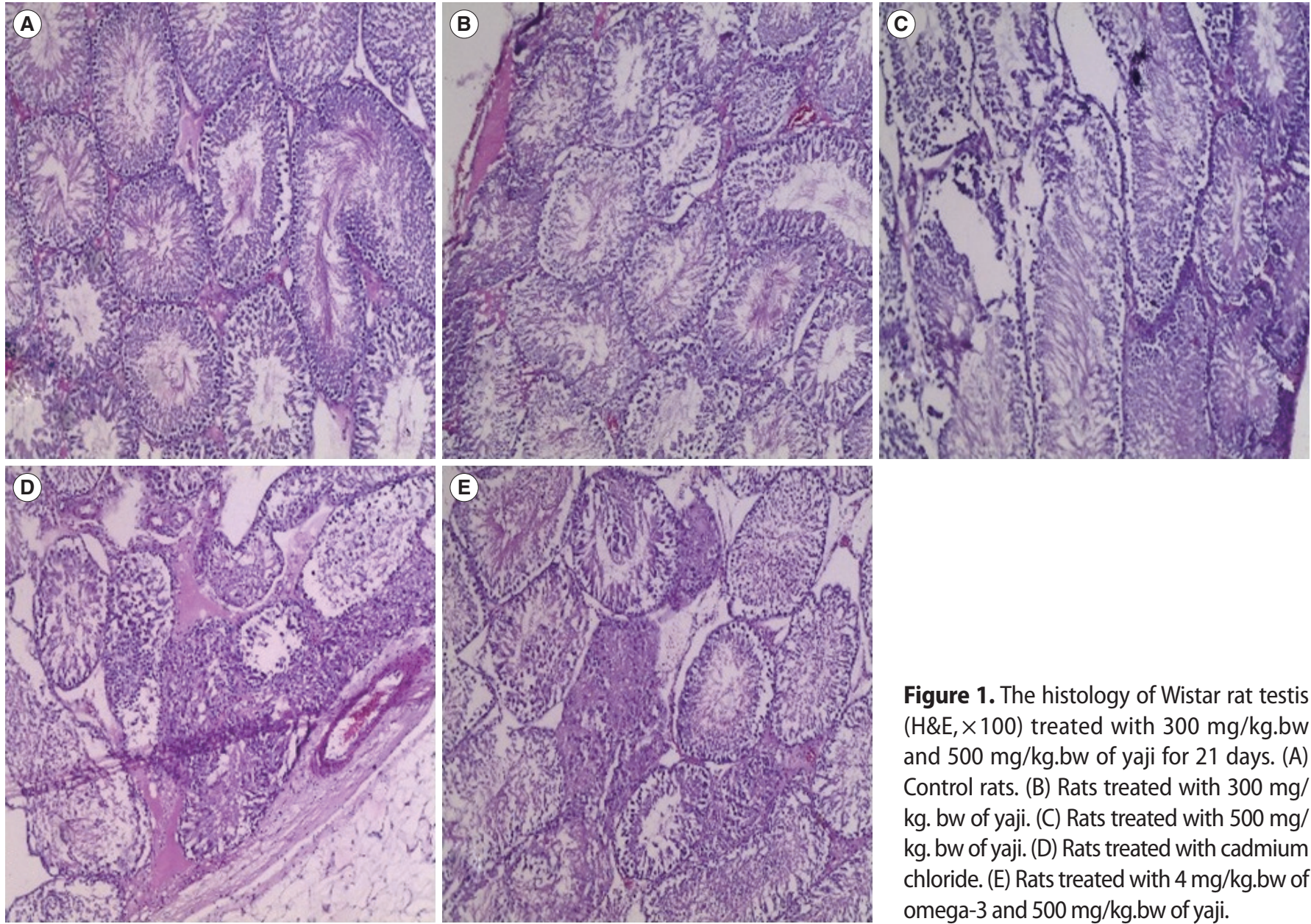

Figure 1. The histology of Wistar rat testis $(H \& E, \times 100)$ treated with $300 \mathrm{mg} / \mathrm{kg} . \mathrm{bw}$ and $500 \mathrm{mg} / \mathrm{kg} . \mathrm{bw}$ of yaji for 21 days. (A) Control rats. (B) Rats treated with $300 \mathrm{mg} /$ kg. bw of yaji. (C) Rats treated with $500 \mathrm{mg} /$ kg. bw of yaji. (D) Rats treated with cadmium chloride. (E) Rats treated with $4 \mathrm{mg} / \mathrm{kg} . \mathrm{bw}$ of omega-3 and $500 \mathrm{mg} / \mathrm{kg}$. bw of yaji.

in testicular superoxide dismutase activity and malonaldehyde levels. As shown in Figures 1 and 2, the histological tissues of the control group (Figures $1 \mathrm{~A}$ and $2 \mathrm{~A}$ ) showed normal features of the seminiferous tubules and interstitial Leydig cells. Similarly, the histoarchitec- 

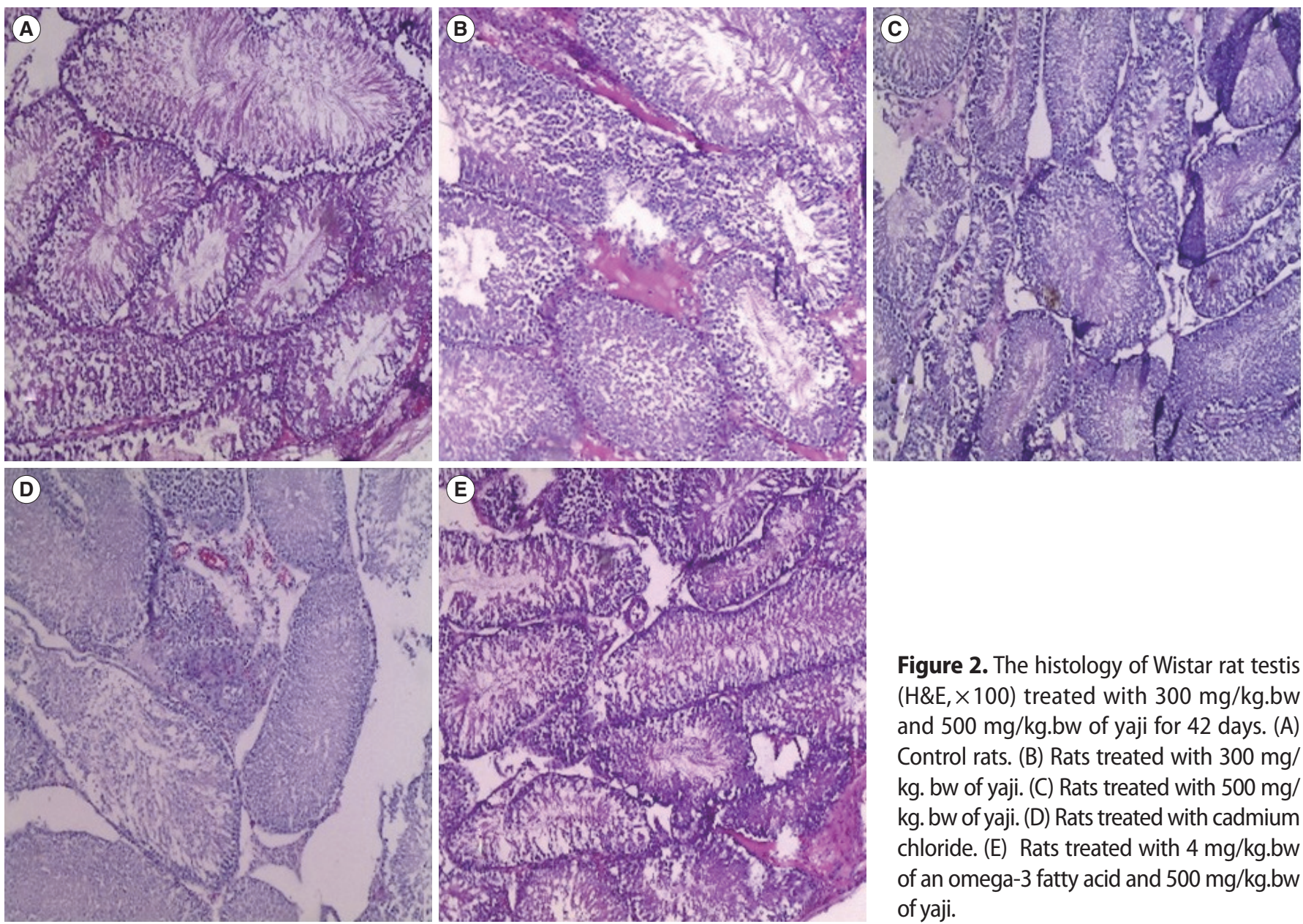

Figure 2. The histology of Wistar rat testis $(\mathrm{H} \& \mathrm{E}, \times 100)$ treated with $300 \mathrm{mg} / \mathrm{kg} . \mathrm{bw}$ and $500 \mathrm{mg} / \mathrm{kg} . b w$ of yaji for 42 days. (A) Control rats. (B) Rats treated with $300 \mathrm{mg} /$ kg. bw of yaji. (C) Rats treated with $500 \mathrm{mg} /$ kg. bw of yaji. (D) Rats treated with cadmium chloride. (E) Rats treated with $4 \mathrm{mg} / \mathrm{kg} . \mathrm{bw}$ of an omega-3 fatty acid and $500 \mathrm{mg} / \mathrm{kg} . \mathrm{bw}$ of yaji.

ture of the testis in rats treated with $300 \mathrm{mg} / \mathrm{kg} . \mathrm{bw}$ of yaji for 21 days (Figure 1B) appeared to be normal, but the testis of rats treated with a similar dose for 42 days (Figure $2 \mathrm{~B}$ ) showed the presence of vascular congestion. It was also observed that $500 \mathrm{mg} / \mathrm{kg}$.bw of yaji caused degeneration of the seminiferous tubules and germinal epithelium following treatment for 21 days (Figure 1C), and the tissue deterioration had progressed further after 45 days of treatment (Figure $2 \mathrm{C}$ ). $\mathrm{CdCl}_{2}$ treatment for 21 days (Figure 1D) caused necrotic changes in the seminiferous tubules and edematous formations in the interstitial cells. Prolonged $\mathrm{CdCl}_{2}$ treatment (Figure 2D) caused further testicular assault, with the presence of atrophied seminiferous tubules and interstitial fibrosis. The testes of rats co-administered $4 \mathrm{mg} / \mathrm{kg}$. bw of the omega-3 fatty acid and $500 \mathrm{mg} / \mathrm{kg}$.bw of yaji (Figures $1 \mathrm{E}$ and $2 \mathrm{E}$ ) showed similar histomorphological features to those of the control, as shown by an ameliorated condition of the seminiferous tubules and improvements in the integrity of interstitial cells.

\section{Discussion}

This study was undertaken to investigate the effects of yaji on re- productive function in adult male rats. The present study showed that yaji had negative effects on the sperm count, progressive motility, percentage of sperm with normal morphology, and the gonadosomatic index, with significant $(p<0.05)$ changes in rats treated for 21 days and 42 days. This finding supports the findings of previous studies that yaji sauce has the potential to reduce reproductive capacity and has negative consequences for spermatogenesis and sperm maturation, as well as the histological features of the male reproduction organs [45]. The effect of yaji is as a result of piperine, one of its constituents that has been implicated in DNA damage [46], germ cell and seminiferous tubule damage [47], spermatogenic arrest [48], and the impairment of reproductive function, induction of $O S$, and triggering of apoptosis [49]. A previous study has associated monosodium glutamate from white maggi (Ajinomoto, one of the constituents of yaji) with oligozoospermia and increased abnormal sperm morphology [50]. Furthermore, it has been demonstrated that clove oil and eugenol have spermicidal effects [51,52]. In another study, it was observed that rats treated with ethanolic extract of cloves had fewer sperm than control animals [53]. Similarly, it has been established that high doses of clove extract are toxic to spermatogenesis [54]. 
Sperm deficiency induced by OS is a major idiopathic factor that affects male fertility [55]. The present study proved that yaji has detrimental effects on male reproductive function by increasing the amount of reactive oxygen species in the testes of albino Wistar rats. The seminal plasma is well endowed with an array of antioxidants, such as superoxide dismutase, catalase, and glutathione peroxide. These antioxidants protect spermatozoa against 0 [56]. Yaji was able to induce an imbalance in the pro-oxidant and antioxidant system, with signifcant $(p<0.05)$ reductions in testicular superoxide dismutase, catalase, and glutathione peroxide activity. This adversely affected the spermatogenic function of the testis, as in previous studies where significant declines in superoxide dismutase activity in oligoasthenozoospermia were recorded $[57,58]$. Our findings of a decrease in testicular catalase activity are in accordance with a study where seminal catalase was observed to decrease in infertile men [59]. Similarly in another study, the activities of seminal plasma superoxide dismutase and catalase were significantly lower in asthenozoospermic, oligozoospermic, and teratozoospermic patients than in fertile controls, while MDA concentrations were higher in the infertile subjects [60]. The data of this study also showed a significant $(p<0.05)$ increase in MDA levels following treatment with $500 \mathrm{mg} / \mathrm{kg}$ of yaji for 42 days, which shows that high doses of the suya sauce can cause increased lipid peroxidation in testicular tissues. Previous research reported significantly higher MDA levels in teratozoospermic and asthenozoospermic individuals than in morphologically and progressively motile normal individuals, respectively [61].

The histological findings of the present study revealed that higher doses of yaji damaged the seminiferous tubules, reduced the number of viable sperm and Leydig cells, and destroyed the structural arrangement of the sperm and Leydig cells. This corroborates previous findings that changes in the structural integrity of testes in monosodium glutamate-treated rats were found to show a dosage- and duration-dependent relationship with damage observed in conditions of acute treatment [50]; however, another study reported severe damage after long-term treatment [62]. The above facts therefore suggest that monosodium glutamate in yaji may be a major contributor to the severe destruction of the arrangement of the testicular architecture observed in the present study.

The noticeable adverse histological changes in the seminiferous tubules agree with earlier findings that the seminiferous tubules in piperine-treated rats regressed, showing heavy loss of germinal elements, particularly elongating and mature spermatids [48]. Black pepper contains piperine, which has been identified as cytotoxic; this toxicity is heightened by the presence of tocopherol, suggesting a mechanism of lipid peroxidation [63]. Furthermore, piperine has been implicated in DNA damage [46], germ cell and seminiferous tubule damage [48]; spermatogenic arrest [47], and the impairment of reproductive func- tion, induction of $\mathrm{OS}$, and triggering of apoptosis [49].

The histological findings of the present study can be further explained in terms of the mean values of the gonadosomatic index in the test groups of rats administered varying doses of yaji. The gonadosomatic index is used to measure the sexual maturity of animals in relation to testicular development [64]. Although no significant differences were observed in the gonadosomatic index between the experimental groups and the control group, or within the experimental groups themselves, we observed a decline in the gonadosomatic index with increasing dosages of yaji from groups $B$ to $D$. This dose-dependent effect of yaji on the gonadosomatic index of the experimental groups suggests that the testicular development-and hence, the sexual maturity of young rats - may decline with increasing dosage of yaji.

The results of this study also showed adverse effects of yaji on testosterone, FSH, and LH. Yaji significantly $(p<0.05)$ decreased the serum levels of testosterone, $\mathrm{LH}$, and FSH. The decrease in serum testosterone concentrations observed in this study following yaji sauce treatment is attributed to disruption of the histoarchitecture of the interstitial Leydig cells. Testosterone is secreted by the interstitial cells of Leydig cells in the testes, but only when they are stimulated by LH from the anterior pituitary gland. LH and FSH production was inhibited in a dose- and duration-dependent manner. The inhibition of FSH and $L H$ is related to the neurotoxic effect of yaji on the central nervous system, which can inhibit neural stimuli essential for the release of pituitary gonadotropins [65-67], leading to a decrease in the levels of pituitary gonadotropins essential for initiating and completing spermatogenesis and steroidogenesis in the testis [68].

Furthermore, testosterone plays a major role in spermatogenesis by being the main hormone responsible for spermatogonium conversion and spermatid formation. Therefore, decreased testosterone levels lead to sterility in males. The decrease in the sperm count observed in this study likely resulted from the decrease in testosterone levels. The findings of this study are in accordance with those of previous studies, in which it was established that piperine in yaji decreased serum testosterone and sperm counts in mature male Wistar rats [48]. Omega-3 fatty acid treatment resulted in improvements in the levels of the reproductive hormones of the yaji-exposed rats. Thus, omega-3 fatty acids have a positive effect on the hormones controlling reproduction. This finding is in agreement with Goyal et al. [69], who showed that serum testosterone concentrations and LH concentrations were increased by the addition of omega- 3 fatty acids to the diet of male rabbits. Similarly, Motahareh et al. [70] demonstrated an increase in the number of Leydig cells, repairs of their structure, and a significant increase in testosterone levels of animals receiving omega-3 fatty acids. The mechanism underlying these affects is thought to be linked to the antioxidant properties of omega-3 fatty acids [71]. Therefore, it is plausible to argue that the omega- 3 fatty acid used in 
this study exerted an ameliorating effect on the yaji-induced impairment of testicular function. This amelioration could be partly mediated by the potential of omega- 3 fatty acids to counteract OS in rat reproductive organs via their antioxidant properties.

$\mathrm{CdCl}_{2}$ was observed to decrease the sperm count, progressive motility, the percentage of sperm with normal morphology, and gonadosomatic index to a significant extent $(p<0.05)$ when compared to control rats and rats treated with $300 \mathrm{mg} / \mathrm{kg}$ of yaji. This is similar to recent findings that $\mathrm{CdCl}_{2}$ adversely affected the semen quality of Wistar rats. $\mathrm{CdCl}_{2}$ induced degenerative changes in the testes of the animals [72,73]. Our results are in agreement with those of several other studies that showed that cadmium exerted negative effects on testicular tissues, thereby contributing to male infertility via reductions in sperm quality in humans and rats [74-76]. The serum concentrations of testosterone, $\mathrm{FSH}$, and LH were also significantly $(p<0.05)$ lower than those of control rats and rats treated with $300 \mathrm{mg} / \mathrm{kg}$ of yaji. This result corroborates the findings of other reports that cadmium caused spermatotoxicity, either by disrupting the hypothalamicpituitary axis, or by exerting a direct effect on spermatogenesis through oxidative damage $[77,78]$. Since sperm cell and testicular Leydig cell mitochondria are highly susceptible to cadmium-induced $O S$, the latter mechanism represents the major factor [75].

In this study, it was observed that administration of an omega-3 fatty acid attenuated the detrimental effects of yaji on semen quality. Therefore, it is plausible to suggest that the omega- 3 fatty acid ameliorated the yaji-induced impairment of sperm count, progressive motility, and normal morphology in this study, and that this effect could be partly mediated by its ability to counteract OS within rat reproductive organs. It has been shown that omega-3 supplementation improved spermatogenesis in both animal and human studies [79]. Due to their antioxidant properties, omega-3 fatty acids can reduce testicular damage. This suggests that omega-3 has potential healing properties against the toxic effects of yaji.

In conclusion, administration of yaji sauce had a similar effect on infertility to that of $\mathrm{CdCl}_{2}$ in terms of detrimental changes to semen quality, testosterone levels, gonadotropin levels, testicular OS markers, and histology of the testis. Furthermore, an omega- 3 fatty acid ameliorated the yaji-induced impairment of testicular function in rats.

\section{Conflict of interest}

No potential conflict of interest relevant to this article was reported.

\section{Acknowledgments}

The authors gratefully acknowledge the contributions of the staff of the Anatomy and Biochemistry Departments of Edo University
Iyamho, Nigeria during the experimental phase of the study and when proofreading the manuscript.

\section{ORCID}

Ehitare Ikekhuamen Ekhoye https://orcid.org/0000-0003-0032-9343 Samson Eshikhokhale Olerimi https://orcid.org/0000-0003-3184-8672 Santos Ehizokhale Ehebha https://orcid.org/0000-0001-8044-8267

\section{Author contributions}

Conceptualization: EIE. Data curation: EIE. Formal analysis: EIE, SEO. Fund acquisition \& Methodology: all authors. Project administration: EIE, SEO. Visualization: EIE, SEE. Writing-original draft: EIE. Writing-review \& editing: all authors.

\section{References}

1. World Health Organization. Infertility definitions and terminology [Internet]. Geneva: World Health Organization; 2014 [cited 2020 Jul 10]. Available from: http://www.who.int/reproductivehealth/topics/infertility/definitions/en/index.html.

2. Okonofua FE, Harris D, Odebiyi A, Kane T, Snow RC. The social meaning of infertility in Southwest Nigeria. Health Trans Rev 1997;7:205-20.

3. Adetoro OO, Ebomoyi EW. The prevalence of infertility in a rural Nigerian community. Afr J Med Sci 1991;20:23-7.

4. Ikechebelu J, Adinma Jl, Orie EF, Ikegwuonu SO. High prevalence of male infertility in southeastern Nigeria. J Obstet Gynaecol 2003; 23:657-9.

5. Isidori AM, Pozza C, Gianfrilli D, Isidori A. Medical treatment to improve sperm quality. Reprod Biomed Online 2006;12:704-14.

6. Semet M, Paci M, Saias-Magnan J, Metzler-Guillemain C, Boissier $\mathrm{R}$, Lejeune $\mathrm{H}$, et al. The impact of drugs on male fertility: a review. Andrology 2017;5:640-63.

7. Carre J, Gatimel N, Moreau J, Parinaud J, Leandri R. Does air pollution play a role in infertility? A systematic review. Environ Health 2017;16:82.

8. Corona G, Giagulli VA, Maseroli E, Vignozzi L, Aversa A, Zitzmann $M$, et al. Therapy of endocrine disease: testosterone supplementation and body composition: results from a meta-analysis study. Eur J Endocrinol 2016;174:R99-116.

9. Tuttelmann F, Werny F, Cooper TG, Kliesch S, Simoni M, Nieschlag E. Clinical experience with azoospermia: aetiology and chances for spermatozoa detection upon biopsy. Int J Androl 2011;34: 291-8.

10. Agarwal A, Prabakaran SA. Mechanism, measurement, and pre- 
vention of oxidative stress in male reproductive physiology. Indian J Exp Biol 2005;43:963-74.

11. Saleh RA, Agarwal A, Sharma RK, Said TM, Sikka SC, Thomas AJ $J$. Evaluation of nuclear DNA damage in spermatozoa from infertile men with varicocele. Fertil Steril 2003;80:1431-6.

12. McCann D, Barrett A, Cooper A, Crumpler D, Dalen L, Grimshaw K, et al. Food additives and hyperactive behaviour in 3-year-old and 8/9-year-old children in the community: a randomised, doubleblinded, placebo-controlled trial. Lancet 2007;370:1560-7.

13. Gaby AR. Adverse effects of dietary fructose. Altern Med Rev 2005; 10:294-306.

14. Moore LK. Developing human. 2nd ed. Philadelphia: W.B. Saunders; 2003.

15. Nwaopara AO, Anyanwu LC, Oyinbo CA, Anaikot IC. The histological changes in pancreas of Wister rats fed with diets containing Yaji (Local meat Sauce). J Exp Clin Anat 2004;3:44-7.

16. Krishnaswamy K, Raghuramulu N. Bioactive phytochemicals with emphasis on dietary practices. Indian J Med Res 1998;108:167-81.

17. Surh YJ, Lee SS. Capsaicin, a double-edged sword: toxicity, metabolism, and chemopreventive potential. Life Sci 1995;56:1845-55.

18. Witchtl M. Herbal drugs and phytopharmaceuticals. 3rd ed. Boca Raton: CRC Press; 2004.

19. McGee H. On food and cooking. New York: Scribner; 2004.

20. Uzeh RE, Ohenhen RE, Adeniji OO. Bacterial contamination of tsire-suya, a Nigerian meat product. Pak J Nutr 2006;5:458-60.

21. Nwaopara AO, Anibeze Cl, Akpuaka FC. Induced histological features of hypoxia-ischaemia in the brain of rats fed with diet containing Yaji: the complex Nigerian meat sauce. Res J Appl Sci Eng Technol 2010;2:67-72.

22. El-Din SB, Abd-El Aty OA. Biochemical and immunocytochemical studies of the testicular changes after treatment with Duloxetine hydrochloride and the possible protective effects of omega 3 in adult rat model of depression. AAMJ 2012;10:264-300.

23. Jabbar SA, Mahde MS. Effect of dietary omega 3 essential polyunsaturated fatty acid on reproductive system of male rats that exposed to acrylamide. J Kerbala Univ 2011;9:155-66.

24. Kumar AS, Deepthi KB, Prasad MV, Mary PG, Kumar SS, Swathi M. Evaluation of the protective effects of omega-3 fatty acids against methotrexate induced testicular toxicity in male albino mice. Int J Phytopharmacol 2011;2:48-52.

25. Olutope MA, Solomon SA, Ayantayo AK. Ameliorative and protective effect of omega 3-fatty acid on testicular lipid concentration in ethanol- induced Wistar rats. Am J Biochem 2014;4:25-8.

26. Odewumi CO, Latinwo LM, Ruden ML, Badisa VL, Fils-Aime S, Badisa RB. Modulation of cytokines and chemokines expression by NAC in cadmium chloride treated human lung cells. Environ Toxicol 2016;31:1612-9.
27. BuT, Mi Y, Zeng W, Zhang C. Protective effect of quercetin on cadmium- induced oxidative toxicity on germ cells in male mice. Anat Rec (Hoboken) 2011;294:520-6.

28. Haidry MT, Malik A. Hepatoprotective and antioxidative effects of Terminalia arjuna against cadmium provoked toxicity in albino rats (Ratus norvigicus). Biochem Pharmacol 2014;3:1000130.

29. Abdel Moneim AE, Bauomy AA, Diab MM, Shata MT, Al-Olayan EM, El-Khadragy MF. The protective effect of Physalis peruviana L. against cadmium-induced neurotoxicity in rats. Biol Trace Elem Res 2014;160:392-9.

30. Nair AR, Lee WK, Smeets K, Swennen Q, Sanchez A, Thevenod F, et al. Glutathione and mitochondria determine acute defense responses and adaptive processes in cadmium-induced oxidative stress and toxicity of the kidney. Arch Toxicol 2015;89:2273-89.

31. Baiomy AA. Protective role of grape seeds extract against cadmium toxicity in the lung of male wistar rats. J Cytol Histol 2016; 5(004).

32. Nwaopara AO, Odike MA, Inegbenebor U, Nwaopara SO, Ewere $\mathrm{Gl}$. A comparative study on the effects of excessive consumption of ginger, clove, red pepper and black pepper on the histology of the Kidney. Pak J Nutr 2008;7:287-91.

33. Masopust J. Clinical biochemistry (in Czech). Prague: Karolinium; 2000.

34. Nwaopara AO, Odike MA, Inegbenebor U, Adoye MI. The combined effects of excessive consumption of ginger, clove, red pepper and black pepper on the histology of the liver. Pak J Nutr 2007; 6:524-7.

35. Nwaopara AO, Anibeze C, Akpuaka F. Histological signs of neurodegeneration in the cerebrum of rats fed with diet containing Yaji: the complex Nigerian suya meat sauce. Asian J Med Sci 2010; 2:16-21.

36. Nwaopara AO, Odike MA, Inegbenebor U, Nwaopara SO, Ekhoye El. A comparative study on the effects of excessive consumption of ginger, clove, red pepper and black pepper on the histology of the heart. Electron J Biomed 2008;3:61-4.

37. Zemjanis R. Collection and evaluation of semen. In: Zemjanis R, editor. Diagnostic and therapeutic techniques in animal reproduction. Baltimore: William and Wilkins; 1977. p. 242

38. Pant N, Srivastava SP. Testicular and spermatotoxic effects of quinalphos in rats. J Appl Toxicol 2003;23:271-4.

39. Narayana K, Prashanthi N, Nayanatara A, Kumar HH, Abhilash K, Bairy KL. Effects of methyl parathion (o,o-dimethyl o-4-nitrophenyl phosphorothioate) on rat sperm morphology and sperm count, but not fertility, are associated with decreased ascorbic acid level in the testis. Mutat Res 2005;588:28-34.

40. Amann RP. Sperm production rates: the testis. New York: Academic; 1970. 
41. Ohkawa H, Ohishi N, Yagi K. Assay for lipid peroxides in animal tissues by thiobarbituric acid reaction. Anal Biochem 1979;95: 351-8.

42. Marklund S, Marklund G. Involvement of the superoxide anion radical in the autoxidation of pyrogallol and a convenient assay for superoxide dismutase. Eur J Biochem 1974;47:469-74.

43. Sinha AK. Colorimetric assay of catalase. Anal Biochem 1972;47: 389-94.

44. Rotruck JT, Pope AL, Ganther HE, Swanson AB, Hafeman DG, Hoekstra WG. Selenium: biochemical role as a component of glutathione peroxidase. Science 1973;179:588-90.

45. Ukoha UU, Egwu OA, Dimkpa U, Maduka SO, Okafor Jl, Ndukwe, $\mathrm{U}$, et al. Histological and weight changes in testes of male albino rats fed with diets containing Yaji (a local meat sauce). Int J Health Sci Res 2014;4:118-26.

46. Piyachaturawat $P$, Kingkaeohoi S, Toskulkao C. Potentiation of carbon tetrachloride hepatotoxicity by piperine. Drug Chem Toxicol 1995;18:333-44.

47. Malini T, Arunakaran J, Aruldhas MM, Govindarajulu P. Effects of piperine on the lipid composition and enzymes of the pyruvatemalate cycle in the testis of the rat in vivo. Biochem Mol Biol Int 1999;47:537-45.

48. Malini T, Manimaran RR, Arunakaran J, Aruldhas MM, Govindarajulu P. Effects of piperine on testis of albino rats. J Ethnopharmacol 1999;64:219-25.

49. D'Cruz SC, Vaithinathan S, Saradha B, Mathur PP. Piperine activates testicular apoptosis in adult rats. J Biochem Mol Toxicol 2008;22:382-8.

50. Nwaopara, AO, Odike MA, Ikhuoriah TA, Anyanwu LC. Potential health hazards in Yaji: the complex suya meat sauce. Medilink J 2007;8:34-8.

51. Buch JG, Dikshit RK, Mansuri SM. Effect of certain volatile oils on ejaculated human spermatozoa. Indian J Med Res 1988;87:361-3.

52. Mishra RK, Singh SK. Safety assessment of Syzygium aromaticum flower bud (clove) extract with respect to testicular function in mice. Food Chem Toxicol 2008;46:3333-8.

53. Dehghani F, Heshmatpour A, Panjeshanin M, Talaei-Khozaniet T. Toxic effects of water/alcoholic extract of Syzygium aromaticum on sperm quality, sex hormones and reproductive tissues in male mouse. Eur J Biol 2012;71:95-102.

54. Chaieb K, Hajlaoui H, Zmantar T, Kahla-Nakbi AB, Rouabhia M, Mahdouani $\mathrm{K}$, et al. The chemical composition and biological activity of clove essential oil, Eugenia caryophyllata (Syzigium aromaticum L. Myrtaceae): a short review. Phytother Res 2007; 21:501-6.

55. Ashkani H, Akbari A, Heydari ST. Epidemiology of depression among infertile and fertile couples in Shiraz, southern Iran. Indi- an J Med Sci 2006;60:399-406.

56. Zini A, Garrels K, Phang D. Antioxidant activity in the semen of fertile and infertile men. Urology 2000;55:922-6.

57. Gil-Guzman E, Ollero M, Lopez MC, Sharma RK, Alvarez JG, Thomas AJ Jr, et al. Differential production of reactive oxygen species by subsets of human spermatozoa at different stages of maturation. Hum Reprod 2001;16:1922-30.

58. Siciliano L, Tarantino P, Longobardi F, Rago V, De Stefano C, Carpino A. Impaired seminal antioxidant capacity in human semen with hyperviscosity or oligoasthenozoospermia. J Androl 2001; 22:798-803.

59. Khosrowbeygi A, Zarghami N. Levels of oxidative stress biomarkers in seminal plasma and their relationship with seminal parameters. BMC Clin Pathol 2007;7:6.

60. Zelen I, Mitrovic M, Jurisic-Skevin A, Arsenijevic S. Activity of superoxide dismutase and catalase and content of malondialdehyde in seminal plasma of infertile patients. Med Pregl 2010;63: 624-9.

61. Shiva M, Gautam AK, Verma Y, Shivgotra V, Doshi H, Kumar S. Association between sperm quality, oxidative stress, and seminal antioxidant activity. Clin Biochem 2011;44:319-24.

62. Ihab M. The effects of the oral dosage of monosodium glutamate applied for short- and long-terms on the histology and ultrastructure of testes of the adult rats. J Anim Veter Adv 2012;11:124-33.

63. Unchern S, Saito H, Nishiyama N. Death of cerebellar granule neurons induced by piperine is distinct from that induced by low potassium medium. Neurochem Res 1998;23:97-102.

64. Barber BJ, Blake NJ. Reproductive physiology. In: Shumway SE, Parsons GJ, editors. Biology and aquaculture. Amsterdam: Elsvier; 2006. p. 133-223.

65. Nwaopara AO, Anibeze Cl, Akpuaka FC. Histological signs of oligodendroglioma in the brain of rats fed with diet containing Yaji: the complex Nigerian suya meat sauce. J Clin Rev Opin 2009; $1: 21-5$.

66. Nwaopara AO, Oyadonghan GP, Olugbenga MA, Ujaddughe MO, Ekoh SN. The combined incidence of grade II and grade IV astrocytoma in the brain of rats fed with diet containing Yaji: a complex Nigerian Suya meat sauce. Int J Basic Appl Innov Res 2012; 1:116-21.

67. Ankarcrona M, Dypbukt JM, Bonfoco E, Zhivotovsky B, Orrenius S, Lipton SA, et al. Glutamate-induced neuronal death: a succession of necrosis or apoptosis depending on mitochondrial function. Neuron 1995;15:961-73.

68. Aydos K, Guven MC, Can B, Ergun A. Nicotine toxicity to the ultrastructure of the testis in rats. BJU Int 2001;88:622-6.

69. Goyal HO, Braden TD, Mansour M, Williams CS, Kamaleldin A, Srivastava KK. Diethylstilbestrol-treated adult rats with altered 
epididymal sperm numbers and sperm motility parameters, but without alterations in sperm production and sperm morphology. Biol Reprod 2001;64:927-34.

70. Motahareh B, Haidar A, Seyed EH, Saeed CA. Effects of walnut oil on plasma levels of testosterone pre and post puberty in male rats. Am J Ethnomed 2014;4:266-75.

71. Zak A, Zeman M, Tvrzicka E, Stolba P. The effect of fish oil on metabolic parameters in patients with type 2 diabetes mellitus associated with dyslipidemia. Cas Lek Cesk 1996;135:354-9.

72. Ekhoye El, Nwangwa EK, Aloamaka CP. Changes in some testicular biometric parameters and testicular function in cadmium chloride administered Wistar rats. Br J Med Res 2013;3:2031-41.

73. Ige SF, Olaleye SB, Akhigbe RE, Akanbi TA, Oyekunle OA, Udoh UA. Testicular toxicity and sperm quality following cadmium exposure in rats: ameliorative potentials of Allium cepa. J Hum Reprod Sci 2012;5:37-42.

74. Akunna GG, Saalu LC, Ogunlade B, Enye LA. Spermatotoxicity in animal models exposed to fragrance components. J Med Sci 2014; 14:46-50.

75. Khanna S, Mitra S, Lakhera PC, Khandelwal S. N-acetylcysteine effectively mitigates cadmium-induced oxidative damage and cell death in Leydig cells in vitro. Drug Chem Toxicol 2016;39: 74-80.

76. Mendiola J, Moreno JM, Roca M, Vergara-Juarez N, Martinez-Garcia MJ, Garcia-Sanchez A, et al. Relationships between heavy metal concentrations in three different body fluids and male reproductive parameters: a pilot study. Environ Health 2011;10:6.

77. Xu LC, Wang SY, Yang XF, Wang XR. Effects of cadmium on rat sperm motility evaluated with computer assisted sperm analysis. Biomed Environ Sci 2001;14:312-7.

78. Roychoudhury S, Massanyi P, Bulla J, Choudhury MD, Lukac N, Filipejova T, et al. Cadmium toxicity at low concentration on rabbit spermatozoa motility, morphology and membrane integrity in vitro. J Environ Sci Health A Tox Hazard Subst Environ Eng 2010; 45:1374-83.

79. Tavilani H, Doosti M, Abdi K, Vaisiraygani A, Joshaghani HR. Decreased polyunsaturated and increased saturated fatty acid concentration in spermatozoa from asthenozoospermic males as compared with normozoospermic males. Andrologia 2006;38: 173-8. 